Humaniora. Czasopismo Internetowe

$\operatorname{Nr} 2$ (30)/2020, ss. 23-46

\author{
ANTONI SZWED \\ Uniwersytet Pedagogiczny w Krakowie \\ Instytut Filozofii i Socjologii \\ e-mail: antoni.szwed@up.krakow.pl \\ ORCID: 0000-0002-8255-3308
}

\title{
Matthew Tindal i redukcja chrześcijaństwa do religii naturalnej*
}

\begin{abstract}
In his Christianity as Old as the Creation Matthew Tindal has reduced Christian religion to the natural religion. His reduction was the last stage of purification of Protestant religion from its supernatural elements. This whole process was taking place in England between 1534 and 1730. The main conclusion of this English deist sounded: the revealed religion was the only repetition of the eternal natural religion, based on the law of nature and human reason. Simultaneously he claimed that any Christian proprium (specific Christian content) did not exist in relation to any other non Christian religion. In this article I put this problem through critical assesment, making analysis of Tindal's argumentation and confronting it with (to some degree) Thomas Becconsall views, expressed in his The Grounds and Foundation of Natural Religion. In contrast to Becconsall Tindal understands the nature of man in another way. This latter rejects the opinion that human nature was burdened with certain moral ineffectuality. According to it human being is more prone to misdeeds than to good deeds. In Christian religion it was possible to explain by the original sin and its hereditary effects in the history of mankind. Matthew Tindal rejects this Christian dogma. In reality he understands man's existence in the state of pure nature and with reason acting without limitations. It corresponds to the situation of man before the Fall into the original sin. But Tindal is not any atheist. He is convinced of God's existence as the Creator of the world and people. The reason of human beings participates in the light of Divine Wisdom. Thus cognition of God and human moral duties are possible (in practice) by intellectual effort directed to the sensible creatures only. This kind of rational
\end{abstract}

* Artykuł z projektu finansowanego z funduszów Narodowego Centrum Nauki, zgodnie z decyzją 2012/07/B/HS1/00358 
investigation is characteristic for methaphysical cognition. In fact, there is small step from deism to atheism. English Enlightenment, based on the enlightened reason, was initially deistic character, afterwards on the Continent (especially in France) it quickly assumed atheistic form. In considerable degree it was possible owing to English deists like Matthew Tindal. They draw the ultimate conclusion from the plurality of Protestant denominations.

Keywords: natural religion, law of nature, Christian Revelation, Deism, Matthew Tindal

$\mathrm{M}$ atthew Tindal (1657-1733) był niewątpliwie najbardziej reprezentatywnym przedstawicielem angielskiego deizmu, zaś jego główne dzieło Christianity as Old as the Creation, opublikowane w Londynie w 1730 r., uchodzi za główny wykład tej myśli. Deizm Tindala stanowił istotny składnik myśli angielskiego Oświecenia, zaś pogląd, że chrześcijaństwo jest równie stare jak stworzony przez Boga świat, był swoistym podsumowaniem refleksji innych deistów angielskich ${ }^{1}$. Nie tylko jednak, bowiem sami deiści nie byli pierwszymi ani jedynymi racjonalistami, którzy wyrośli na krytyce angielskiego kalwinizmu. W wielu przypadkach kontynuowali idee latytudynarian, czyli teologów liberalnych, których apogeum intelektualnej aktywności przypada na drugą połowę XVII wieku. Latytudynarianie byli swobodnymi (liberalnymi) teologami, którzy w większości pojawili się w okresie Restauracji, czyli w okresie przywrócenia w Anglii monarchii. Zdali oni sobie sprawę z tego, że nie należy zgadzać się na cały ten polityczno-religijny zamęt, który szczególnie mocno dał o sobie znać podczas Wojny Cywilnej (Civil War) w latach 1642-1649, zakończonej pokonaniem wojsk Karola I i ścięciem króla (31 stycznia 1649) oraz wprowadzeniem dyktatury purytańskiej większości parlamentarnej wraz z jej przywódcą, protektorem Oliverem Cromwellem (1599_ 1658). Latytudynarianie byli ludźmi dobrze wykształconymi nie tylko w teologii, ale również w filozofii. Wykształcenie zdobywali na najlepszych uniwersytetach kraju, w Cambridge lub Oksfordzie ${ }^{2}$. Mniej lub bardziej ściśle współpracowali z nimi filozofowie, platonicy z Cambridge ${ }^{3}$. Z tymi grupami uczonych mieli kontakt ci uczeni, którzy oprócz zainteresowań filozoficznych i teologicznych aktywnie uczestniczyli w ówczesnym rozwoju nauk przyrodniczych ${ }^{4}$.

${ }^{1}$ Należą do nich: Edward Herbert Lord Cherbury (1583-1648), Charles Blount (1659-1693), Anthony Collins (1676-1729), John Toland (1670-1722), Thomas Woolston (1669-1733) i kilku innych.

2 Do latytudynarian zaliczano Josepha Glanvilla (1636-1680), Johna Tillotsona (1630 1694), Simona Patricka (1626-1707), Edwarda Stillingfleeta (1635-1699), Gilberta Burneta (1643-1715).

${ }^{3}$ Najbardziej znani i wpływowi pośród nich to: Benjamin Whichcote (1609-1683), John Smith (1618-1652), Henry More (1614-1687), Nathaniel Culverwell (1619-1651), Peter Sterry (1613-1672), John Worthington (1618-1671).

${ }^{4}$ I znowu trzeba wymienić Johna Wilkinsa (1614-1672), Thomasa Sprata (1635-1713) czy teologa, fizyka i chemika Roberta Boyle’a (1627-1691). Oczywiście, pośród nich pierwsze miejsce zajmował Isaac Newton (1643-1727), którego tu także trzeba przywołać. Genialny matematyk i fizyk, który równie pilnie zajmował się egzegezą Pisma Świętego, był jednak samotnikiem, 
Wszyscy oni starali się pokazać - na różne sposoby, oczywiście - że radykalnie pojmowana religia chrześcijańska jest nie do utrzymania. Nie będąc ateistami, ani wrogami chrześcijańskiej religii objawionej, wskazywali na jej istotne mankamenty, które szczególnie widoczne były z punktu widzenia czystego kalwinizmu, reprezentowanego przez purytanów. Bardziej ugodowi kalwiniści (prezbiterianie) stanowili wpływową część oficjalnego Kościoła Anglii w czasach monarchii, ale wraz z radykałami szybko stawali się dominującą religijnie, ekonomicznie i politycznie warstwą społeczeństwa angielskiego. Później, mając w Parlamencie większość, zreformowali tenże Kościół wedle własnej wizji, obalając między innymi angielski episkopat. Purytanie byli głównym motorem przemian nie tylko w życiu politycznym XVI i XVII wieku, ale także w sferze moralno-religijnej i intelektualnej. Stąd nie dziwi, że wyżej wymienieni intelektualiści tego okresu pochodzili przeważnie z głęboko religijnych rodzin purytańskich. Wychowani w duchu radykalnego kalwinizmu pogłębiali znajomość tej doktryny na studiach, najczęściej odbywanych w którymś z college’ów Uniwersytetu w Cambridge, który w tamtych czasach ${ }^{5}$ był właśnie ostoją kalwińskiego radykalizmu. Rychło jednak doszli do przekonania, że ich wiara jest przesycona pierwiastkami irracjonalnymi, fideistycznymi, zaś wiele z jej elementów dotychczas przyjmowano bezrefleksyjnie jako swoiste tajemnice. Postulat dosłownego rozumienia Pisma Świętego jako Słowa Boga, głoszony przez Jana Kalwina (1509-1564), w zasadzie wykluczał pośrednictwo filozoficznego rozumu, z wyjątkiem akceptowanych zasad Arystotelesowskiej sylogistyki ${ }^{6}$, którą posługiwano się do wyciągania wniosków z odczytywanych biblijnych przesłanek. Dosłowne pojmowanie tekstu Starego i Nowego Testamentu z wykluczeniem interpretacji alegorycznej doprowadziło Kalwina i jego gorliwych zwolenników do fideistycznych konkluzji. Mocnym przejawem tego kalwińskiego fideizmu była doktryna podwójnej predestynacji, którą reformator z Genewy starannie wyłożył w Institutio christianae religionis ${ }^{7}$. Ta bardzo kontrowersyjna doktryna stała się później zarzewiem niekończących się dyskusji i podziałów religijnych w łonie samego kalwinizmu.

Autor Institutio przyjmował, że każde słowo znajdujące się w Piśmie Świętym jest Słowem Boga, podyktowanym autorom Ksiąg Pisma wprost przez Ducha Świętego. Wierzący chrześcijanin, odczytując te słowa, pojmował ich sens, ponieważ w trakcie lektury również pozostawał pod natchnieniem Ducha Świętego. Dlatego

niechętnie udzielającym się publicznie. Zasadniczo nie brał udziału w dyskusjach, nawet wtedy, gdy w 1703 r. został przewodniczącym Królewskiego Towarzystwa (Royal Society). W jego imieniu dyskutował i prowadził korespondencję np. z Leibnizem Samuel Clarke (1675-1729).

${ }^{5}$ Zwłaszcza za rządów protektora Olivera Cromwella (1599-1658), głównie w latach 1649-1658).

${ }^{6}$ Później często zastępowanej uproszczoną jej wersją, opracowaną przez Petera Ramusa (1515-1572), francuskiego hugenoty, który zginął podczas Nocy św. Bartłomieja w sierpniu 1572 r. w Paryżu.

${ }^{7}$ W wydaniu ostatnim z 1559 r. jest ona zawarta w księdze trzeciej, w rozdziałach 21-24. 
niejako z założenia wierzący chrześcijanin - Kalwin uznawał zasadę podwójnego natchnienia Ducha Świętego ${ }^{8}$ - nie mógł błędnie odczytywać Pisma. Oczywiście, tymi prawdziwie wierzącymi chrześcijanami byli zwolennicy Kalwina, ale już nie papiści ${ }^{9}$. Szybko jednak okazało się, że w łonie samego kalwinizmu zaczęły się mnożyć religijne podziały. Pierwszym znaczącym odejściem od ortodoksji kalwińskiej było powstanie arminianizmu ${ }^{10} \mathrm{w}$ Niderlandach. Natomiast w oficjalnym Kościele Anglii doktryna kalwinizmu zderzyła się z pozostałościami katolicyzmu, dając początek doktrynie anglikańskiej. Powstała z tego zderzenia doktryna była kompromisem, na który zgadzali się umiarkowani kalwiniści (prezbiterianie), lecz odrzucali kalwiniści radykalni, tacy jak: niezależni (independenci, kongregacjoniści) czy separatyści. Różnili się oni w swoich egzegezach Pisma Świętego, mimo że wyrastali z tego samego genewskiego pnia. Tym bardziej widać to było na poziomie rozwijanych teologii, które jeszcze bardziej powiększyły różnice egzegetyczne. Teologiczne rozdźwięki pojawiały się wraz z pytaniem: która egzegeza jest poprawna i jak to rozstrzygnąć. To pytanie jako jeden z pierwszych zadał sobie William Chillingworth (1602-1644), który niebawem stał się prekursorem swobodnej teologii. To on w swoim głównym dziele The Religion of Protestants. A Safe Way to Salvation (1638) odszedł od zasady podwójnej asystencji Ducha Świętego, głosząc potrzebę ustanowienia racjonalnego kryterium rozstrzygania. Odwołał się do sądu ludzkiego rozumu jako głównego arbitra w interpretowaniu biblijnych treści. W oparciu o to kryterium Chillingworth wprowadził podział prawd na: fundamentalne, konieczne do zbawienia, i niefundamentalne, niekonieczne do zbawienia, które, owszem, można przyjmować, ale nie są one istotne dla osiągnięcia przez chrześcijanina najwyższego celu, jakim jest zbawienie wieczne.

W drugiej połowie XVII wieku w teologicznej myśli angielskiej pojawia się coraz pilniejsza potrzeba dowartościowania rozumu. W takiej sytuacji coraz mocniejszym konkurentem chrześcijańskiej religii objawionej staje się coś, co zostaje nazwane religią naturalną, odwołującą się z jednej strony do szeroko rozumianej natury stworzonej przez Boga, z drugiej do zdolności poznawczych ludzkiego rozumu. W dużym skrócie rzec można, że w coraz większym stopniu dzieło stworzenia zaczyna jakby konkurować z dziełem odkupienia. Reformacja kładła bowiem nacisk na zbawienie człowieka, a reformatorzy poniekąd spychali na drugi plan to, że Bóg najpierw stworzył świat natury wraz z istotami ludzkimi, a dopiero później

${ }^{8}$ Por. J. Kalwin, Institutio christianae religionis (dalej: Institutio), III. 1.1; III. 1.3; III. 2.5 (cyfra rzymska oznacza księgę, pozostałe cyfry, kolejno: rozdział i paragraf).

${ }^{9}$ Wierni Kościoła rzymsko-katolickiego, uznający papieża za widzialnego zastępcę Chrystusa na ziemi.

${ }^{10}$ Na przełomie XVI i XVII wieku doszło do powstania sekty arminian, zwolenników Jakuba Arminiusza (1560-1609), który z pomocą sylogistyki dowiódł na Uniwersytecie w Lejdzie, że teoria podwójnej predestynacji Kalwina jest błędna nie tylko z teologicznego, ale również z logicznego punktu widzenia. Obszerniej na ten temat w: A. Szwed. Fideizm Kalwina i bunt angielskich racjonalistów, Wydawnictwo Marek Derewiecki, Kęty 2016, s. 123-148. 
zaistniała potrzeba odkupienia człowieka przez Jezusa Chrystusa. Ale ta deprecjacja stworzenia nie była przypadkowa. Reformatorzy: Luter, Kalwin i ich bezpośredni następcy mówili o niszczycielskich skutkach grzechu pierworodnego poczynionych w naturze ludzkiej, i to w znacznie większym stopniu niż kiedykolwiek przedtem, przed Reformacją miało to miejsce. Byli przekonani, że widocznymi skutkami tego grzechu było między innymi całkowite „oślepienie” rozumu, „pogrążenie go w mroku”, przez co nie był on zdolny do tego, by „pojąć wolę Boga”. Dlatego rozum ludzki został pozbawiony światła. Mógł być oświecony jedynie dzięki Bożej łasce, czyli w sposób nadnaturalny, nie zaś w sposób naturalny ${ }^{11}$. Trzeba przyznać, że Kalwin był pod tym względem mniej radykalny niż Luter i luteranie ${ }^{12}$. Mówił o stworzonym świecie jako „najpiękniejszej księdze”. Potrafił zachwycić się światem, rozgwieżdżonym nocą nieboskłonem, ale był to zachwyt estetyczny, który go nie skłaniał do jakichś głębszych zainteresowań przyrodą. Kalwin był przekonany, że przyrodzony świat jest taką księgą, której w istocie nie potrafimy odczytać, gdyż bardzo niewyraźne są naturalne ślady Boga w Jego dziełach. Owszem, daje się je dostrzec, ale by mogły być właściwie zinterpretowane, muszą być istotnie uzupełnione przez Objawienie zawarte w Piśmie Świętym ${ }^{13}$.

Teraz nadchodził czas zainteresowania się dziełem Boskiego stworzenia, które można było poddać operacjom poznawczym zarówno w sensie ogólnym: filozoficznym, jak i w sensie bardziej szczegółowym, dzięki rozwijającym się naukom przyrodniczym, a także nowym badaniom etycznym. Te ostatnie zdominowały zainteresowania swobodnych teologów i filozofów natury. Pierwszym autorem, który wyraźnie odróżniał chrześcijańską religię objawioną od religii naturalnej był jednak teolog purytański Richard Baxter (1615-1691) w dziele The Reasons of the Christian Religion (1667). Pod koniec XVII wieku pojawia się szereg prac swobodnych teologów postpurytańskich, a także anglikańskich. Pośród nich warto wymienić kilka najważniejszych: Johna Wilkinsa (1614-1672) Of the Principles and Duties of Natural Religion (1675), Thomasa Becconsalla (1663-1709) The Grounds and Foundation of Natural Religion (1698), Johna Tillotsona (1630-1694), Of the Great Duties of Natural Religion (1722), Stephena Nye'go (1648-1719), A Discourse Concerning Natural and Revealed Religion (1696).

Matthew Tindal nigdy nie cieszył się taką sławą i nie był takim autorytetem pośród filozofów, jak np. John Locke (1632-1704), ale jego dzieło życia Christianity as Old as the Creation stało się głośne w latach 30. XVIII wieku. Od razu zyskało zwolenników, ale i zagorzałych przeciwników ${ }^{14}$. Stało się powodem gorących

${ }^{11}$ J. Kalwin, Institutio, III. 2.7.

12 Por. Formula Concordiae, II , ”Solida Declaratio”, I, 6 (wyd. pol. Formuła Zgody z 1577 roku, tłum. bp Józef Pośpiech, Ośrodek Wydawniczy „Augustana”, Bielsko-Biała 1999, ss. 89-90).

${ }_{13}$ J. Kalwin, Institutio, I. 6. 1-2.

${ }^{14}$ Z Mateuszem Tindalem polemizowali między innymi: Anthony Atkey, The Main Argument Of a late Book, Intitled Christianity as Old as the Creation, London 1733; Benjamin Atkinson, 
polemik, gdyż stanowiło dosyć czytelne zebranie argumentów wcześniejszych autorów na rzecz religii naturalnej, jednocześnie Tindal dodawał coś od siebie, co wykraczało poza konstatacje poprzedników. Odrzucił niemal całkowicie autorytet Boskiego Objawienia, choć w wyżej cytowanym dziele nie wyrażał tego wprost, przeciwnie, starał się pokazać, że chrześcijańską religię objawioną można utożsamiać z religią naturalną, co faktycznie czyniło tę pierwszą zbędną ${ }^{15}$.

Warto więc zapytać o argumenty na rzecz takiego stanowiska. Co doprowadziło Tindala do wniosku, że religia objawiona - oparta na Boskim Objawieniu zawartym w Piśmie Świętym - jest nic nie wnoszącym powtórzeniem religii naturalnej? Jak to się stało, że taka konkluzja była możliwa? Co skłaniało deistę Tindala do pomijania, a nawet odrzucania tych treści religii chrześcijańskiej (różnych denominacji), które stanowiły o jej proprium, pewną osobliwość w stosunku do wszystkich religii niechrześcijańskich? Czy miało to znaczyć, że religia objawiona na tyle utraciła już swoje dogmatyczne treści, że teraz wtapiała się bez reszty w religijne dociekania ludzkiego rozumu? A przecież do niedawna, tj. do końca XVII wieku, wydawało się to niemal niemożliwe. Wystarczy wziąć pod uwagę któregoś z bardziej znaczących autorów z tego okresu, by się o tym przekonać, np. cytowanego już Thomasa Becconsalla i jego dzieło The Grounds and Foundation of Natural Religion, wydane w 1698 r. Konfrontując opinie Becconsalla i Tindala, łatwiej dostrzec ewolucję poglądów na chrześcijaństwo w myśli angielskiej, tę ewolucję, która dokonała się w ciągu pierwszych 30 lat XVIII wieku i nadała charakterystyczny rys całemu zachodnioeuropejskiemu Oświeceniu.

To, co wydarzyło się między Thomasem Becconsallem a Matthew Tindalem było już ostatnim etapem redukcji religii chrześcijańskiej do religii naturalnej. Stąd warto się mu przyjrzeć, nie zapominając jednak o wcześniejszych etapach, które również miały znaczący wpływ na stopniowe zubożenie treści chrześcijańskiego przesłania.

\section{Becconsall o relacjach między chrześcijańskim objawieniem a religią naturalną}

Autor The Grounds and Foundation of Natural Religion mocno podkreślał wartość i znaczenie religii naturalnej, ale jednocześnie bronił potrzeby odwoływania się do religii chrześcijańskiej, opartej na Objawieniu.

Scripture History, Precepts and Prophecy Vindicated... of Christianity not older than the First Gospel-promise, in Answer to Christianity as Old as the Creation, London 1731; John Leland, An Answer to a Book Intituled Christianity as Old as the Creation, London 1740; Simon Browne, The Close of the Defense of the Religion of Nature and the Christian Revelation: in Answer to Christianity as Old as the Creation, London 1733; Daniel Waterland, Scripture Vindicated. In Answer to a Book Christianity as Old as the Creation (1730).

${ }^{15}$ Tak to widzi współczesny komentator Tindala St. Lalor, Matthew Tindal. Freethinker. An Eighteens-Century Assault on Religion, Continuum, London \& New York 2006, s. 112. 
Ogólne pojęcie „religii” zakłada egzystencjalne odniesienie do Boga, o którym wierzący posiada jakąś wiedzę i któremu skłonny jest oddawać w jakiś sposób cześć oraz podzielać swoją wiarę ze wspólnotą, do której należy. Podzbiorem zbioru ogólnie występujących w świecie religii są religie naturalne, a pośród nich to, co przez religię naturalną rozumieli Becconsall i Tindal. Ich religia naturalna w znaczącym stopniu sprowadzała się do moralności, opartej z jednej strony na definicji „natury”, z drugiej na swoistym określeniu „,rozumu ludzkiego”. Zmieniało się także rozumienie Boga.

Jednym z głównych zadań religii naturalnej było wskazanie kryteriów pozwalających odróżniać moralne dobro od moralnego zła. Becconsall odrzucał takie kryteria, które w jego czasach wielu wierzących chrześcijanin wyciągało z zastanych zwyczajów, przyzwyczajeń, wychowania czy tradycji, jakże krótkiej i wielowątkowej u protestantów. Nie miał wątpliwości, że wszystkie tego typu „źródła” kryteriów moralnych deista z łatwością mógł obalić jako „mistyfikację”. Wtedy równie łatwo było porzucić chrześcijańskie zasady moralności i stać się człowiekiem niereligijnym, a nawet ateistą. Becconsall utrzymywał, że to Bóg jest twórcą początków religii naturalnej (Original of Natural Religion), opartej na prawie natury. Ono zaś określa moralne obowiązki człowieka. Z tego nasz autor wnioskował, że religię naturalną Bóg ustanowił wcześniej niż Objawienie, które przekazał ludziom przez wybrane przez siebie osoby. Ale z tego nie wynika zastrzegał się Becconsall - że można się zgodzić z deistą, iż Objawienie nie jest potrzebne. Wynika tylko tyle, że to Bóg ustanowił prawo natury ${ }^{16}$ jako niezbędną regułę moralnego obowiązku i sposobu działania ludzkości.

I tu autor The Grounds and Foundation of Natural Religion wprost odwoluje się do Listu do Rzymian św. Pawła Apostoła ${ }^{17}$, gdzie jest mowa o tym, iż w sercach pogan, którzy wszak nie znają Objawienia, zostało wyryte Prawo Boże. Zostało więc ogłoszone niezależnie od objawienia tego Prawa w Piśmie Świętym. Poganie dostosowują się do niego z natury, a nie z nadprzyrodzonej łaski Boga. Zapisane w sercach wszystkich ludzi jest fundamentalnym kryterium dobra i zła, bycia sprawiedliwym i niesprawiedliwym. Ono wyprzedza także wszelkie pozytywne prawo ludzkie ${ }^{18}$. Prawo natury (prawo naturalne) odczytuje ludzki rozum, który w świetle tego prawa dyktuje niezbędne reguły moralnego działania i pozwala

${ }^{16}$ Podejrzewa, że gdyby odebrać Bogu autorstwo prawa natury, to znaleźliby się tacy, którzy podstępnie mianowaliby się kreatorami „,sztucznego systemu” (artificial system) praw natury, choćby po to, by mając władzę, wykorzystywać go do zniewalania poddanych.

17 „Bo gdy poganie, którzy Prawa nie mają, idąc za naturą, czynią to, co Prawo nakazuje, chociaż Prawa nie mają, sami dla siebie są Prawem” (Rz 2,14). I dalej: „Wykazują oni, że treść Prawa wypisana jest w ich sercach, gdy jednocześnie ich sumienie staje jako świadek, a mianowicie ich myśli na przemian ich oskarżające lub uniewinniające. [Okaże się to] w dniu, w którym Bóg przez Jezusa Chrystusa sądzić będzie ukryte czyny ludzkie, według mojej Ewangelii” (Rz 2, 15-16).

18 T. Becconsall, The Introduction Concerning the Necessity of Revelation, w: idem, The Grounds and Foundation of Natural Religion, London 1698, s. B3-B4, oraz § 1. 
człowiekowi podejmować decyzje zgodne z wolą Stwórcy. Wtedy rozum jest w stanie określić szereg obowiązków, od spełnienia których zależne jest szczęście jednostki. Niemniej jednak rozum nie jest na tyle doskonały, nie posiada na tyle mocy, by w pełni ochronić człowieka przed popełnianiem moralnego i religijnego zła, czyli grzechu. Dlatego poganie, zgodnie z chrześcijańskim nauczaniem, nadal pozostają w grzechu. Prawdą jest, że obecnie ludzki rozum nie doprowadza nas do pełnego poznania czystego stanu natury. Stąd nie może nam wystarczyć wyłącznie racjonalne poznawanie prawa natury i praktykowanie religii naturalnej, z pominięciem chrześcijańskiego Objawienia ${ }^{19}$. Becconsall jest przekonany, że dają tu o sobie znać skutki grzechu pierworodnego.

Przed Upadkiem Pierwszych Ludzi w raju było inaczej. Doskonale rozpoznawali oni z pomocą rozumu swoje ludzkie natury. Człowiek bowiem wyszedł bez skazy z ręki Boga. Jego natura była czysta, to znaczy: wszystkie wrodzone namiętności i popędy były całkowicie podporządkowane władzom rozumu. Miłość i żarliwość były nakierowane na pomnażanie wiedzy i zdobywanie prawdy. Ludzie żyjący w stanie niewinności potrafili odczytywać swoje obowiązki. Posiadali głębokie rozumienie obowiązku i posłuszeństwa wobec Boga, z którym mieli stałą łączność. Pojmowali głęboki sens dobroci i czystości Boga i byli wypełnieni niegasnącym pragnieniem działania w zgodzie z Jego wolą ${ }^{20}$.

Wszystko to zmieniło się po Upadku Pierwszych Ludzi. Rozum i natura ludzka uległy zepsuciu. Becconsall zarzuca socynianom, deistom i Johnowi Locke’o$\mathrm{wi}^{21}$, że doktrynę o grzechu pierworodnym traktują jak frazes, którym posługują się księża. Przyznaje, że Bóg nam tego nie objawił, w jaki sposób zarażamy się skutkami grzechu pierworodnego, a gdyby objawił - przypuszcza - to i tak byśmy tego nie zrozumieli. Niemniej jednak nasze ludzkie doświadczenie informuje nas o tym, że skutki te faktycznie tkwią w nas. Doświadczamy bowiem jakby dwóch wól działających wedle dwóch praw w nas: prawa kierującego naszą cielesnością i prawa naszego ducha (rozumu). Te prawa są względem siebie przeciwne ${ }^{22}$, co powoduje, że człowiek żyje w rozdwojeniu. „Prawo w członkach ciała” i „prawo rozumu” to jakby dwie odrębne zasady, które wchodzą z sobą w konflikt, stąd potrzebna jest wiedza płynącą z Objawienia, „staje się ona wysoce konieczna”, by ten konflikt sobie uświadomić i go przezwyciężać. W efekcie tego rozum ludzki

19 T. Becconsall, The Grounds and Foundation...., ss. 34-35.

20 T. Becconsall, The Introduction..., § 1.

${ }^{21}$ Głównie w dziele The Reasonableness of Christianity, opublikowanym w 1695 r. Por. J. Locke, The Reasonableness of Christianity, w: Works, vol. 1-10, London 1823; vol. 7, ss. 4-7. Zarzuca Locke’owi, że podaje on w wątpliwość zepsucie ludzkiej natury po grzechu Adama. I wyjaśnia, że po Upadku popadliśmy w niewolę grzechu, zdolności naszego umysłu zostały zablokowane, nastąpił rozpad duchowych zasad.

22 Jak się zdaje, Becconsall idzie tu tropem św. Augustyna, który dosyć obszernie zajmował się problemem dwóch wól działających w człowieku. Por. np. Augustyn, Contra Julianum V, 27-28; PL 44, 801. „Quia dum hic vivimus, ubi caro concupiscit adversus spiritum, et spiritus adversus carnem". 
nie może o własnych siłach funkcjonować poprawnie. Rozum naturalny może nam przedstawiać najbardziej fundamentalne prawa natury, ale jedynie w przybliżony sposób. Dlatego Boskie Objawienie zostało nam dane jako wiedza doskonaląca nasze czysto ludzkie poznanie. Ono w sposób istotny dopełnia naszą wiedzę także w sferze moralnej, nie tylko religijnej. W stanie rajskiej niewinności wystarczało światło naturalnego rozumu, by człowiek mógł dostępować szczęścia, po Upadku już nie. Dlatego najbardziej wyrafinowane odkrycia rozumu ludzkiego nie są w stanie wyciszyć niekończących się uczonych dysput, jeśli zostanie odrzucona wiedza objawiona ${ }^{23}$. Becconsall uznaje Boski autorytet zawarty w Objawieniu, uznaje religię objawioną, ale także oryginalną religię naturalną. Zarzuca deistom, że atakują „wiarę w Boga żywego, wykraczając swoim płytkim rozumieniem ponad sferę nieskończonej mądrości” ${ }^{24}$. Becconsall jest przekonany, że w świecie chrześcijańskim wielu moralnych obowiązków nie trzeba ustalać z pomocą naturalnego rozumu, bo znajdujemy je w Piśmie Świętym i w „zdrowej doktrynie” w nim obecnej. I ta wiedza wystarczy do zbawienia ${ }^{25}$.

\section{Tindal o religii naturalnej}

Dla Becconsalla porzucenie Objawienia jest równoznaczne z pomijaniem pewnej istotnej prawdy o człowieku, mianowicie prawdy o grzechu pierworodnym i jego skutkach. Dlaczego Tindal pomija jeden z najważniejszych dogmatów chrześcijańskich, skupiając swoją uwagę na czystej naturze i opartej na niej religii naturalnego rozumu?

Co Tindal rozumie pod pojęciem religii naturalnej? Przede wszystkim różni się ona od chrześcijańskiej religii objawionej, i - w przeciwieństwie do tej ostatniej oparta jest na znajomości natury, badanej ludzkim rozumem. Trzeba od razu zaznaczyć, że Tindal nie zajmuje się naturą w sensie zewnętrznej, fizycznej przyrody. W Christianity as Old as the Creation nie ma śladu bliższego zainteresowania jej autora niedawnymi odkryciami Isaaca Newtona z zakresu mechaniki i grawitacji czy innych współczesnych mu fizyków. Mówiąc o naturze, w sposób dosyć ogólnikowy wiąże ją z metafizyczną problematyką ,przyczyny i istoty rzeczy” (reason \& nature of things). Wiedza o niej ma więc bardziej charakter metafizyczny niż fizyczny. Tindal pozostaje na gruncie metafizyki, jednocześnie sugerując, że wiedzę tę dosyć łatwo da się osiągnąć, ponieważ, jak sądzi, znajomość przyczyn i istot rzeczy jest ,jasna i oczywista” (plain). Dzięki temu daje się określić „prawo natury” (law of nature), które jest „dyktatem prawego rozumu” (dictatus rectae rationis). Związki między rzeczami Tindal rozumie po platońsku, są one bowiem dostępne w poznaniu niejako a priori, poza empirycznym doświadczeniem. Rozum ludzki

\footnotetext{
${ }^{23}$ T. Becconsall, The Introduction..., § 2, § 3 .

${ }^{24}$ Ibidem, § 5.

25 Ibidem, § 7.
} 
jest posiadaczem „światła natury” (light of nature), które pochodzi od Boga. Wbrew dotychczasowej tradycji kalwińskiej Bóg jest tu przede wszystkim Stwórcą świata natury, a nie Odkupicielem. Jest Bytem „absolutnie doskonałym i nieskończenie szczęśliwym w sobie samym”. Jest „źródłem wszystkich innych bytów” i wszystkie własności „bytów stworzonych” (creatures) pochodzą od Niego. Boga nikt i nic nie dopełnia. Ludzie oraz inne byty stworzone nie są w stanie nic dodać do Bytu Boga ani nic od Niego odjąć. Stąd Tindal wyciąga wniosek, że Bóg nie zabiega u ludzi o swoją chwałę, bo nie musi. A jeśli nadał ludziom prawa, by ich kształtowały, to nie po to, by poznali Jego wolę, lecz dla ich własnego dobra. Tym samym Bóg poprzez nadane prawo natury umożliwia ludziom to, by byli szczęśliwi i nie czynili sobie krzywdy. Religia budowana na takich fundamentach musi być „powszechna” (universal), czyli musi być możliwa do przyjęcia przez wszystkich bez wyjątku ludzi. Rozumowa wiedza, jaką są w stanie zyskać, ma wynikać z „rozważania istoty Boga i człowieka”, z relacji, jakie zachodzą między Bogiem a człowiekiem oraz z relacji między ludźmi. Na tej wiedzy spoczywa religia naturalna (religion of nature), która ma przede wszystkim wymiar moralny. Polega ona na zachowywaniu obowiązków moralnych, na które wskazuje nasz ludzki rozum. Ich praktykowanie zakłada wiarę w istnienie Boga oraz racjonalne rozpoznanie doskonałości Boskich atrybutów. Ważne jest także rozpoznanie naszych ludzkich niedoskonałości w odniesieniu zarówno do Boga, jak i do innych ludzi ${ }^{26}$. Tak pojmowana religia naturalna nie była jakimś oryginalnym odkryciem Tindala. Wcześniej w podobny sposób myślał o niej Benjamin Whichcote ${ }^{27}$. Ogólniej, platonicy z Cambridge byli przeświadczeni o tym, że rozum nie był samoistną ludzką zdolnością, lecz swoją moc czerpał z uczestnictwa w Boskim Rozumie. Kalwiński teolog Richard Baxter uważał nawet, że według platoników rozum może wiedzieć więcej o Boskim Bycie niż to, co o Nim mówi Pismo Święte ${ }^{28}$.

Prawdziwa religia naturalna „polega na stałej dyspozycji umysłu do czynienia każdego dobra, które można uczynić, odnosząc się w ten sposób do celu stworzenia”29. Możemy mieć co do tego pewność, gdyż Bóg jako nieskończona Mądrość działa w stałej zgodności z racjami i istotami rzeczy. Gdyby czynił coś nierozumnego, byłoby to sprzeczne z Jego istotą. Bóg nigdy nie może zatem dawać ludziom nakazów, które odpychałyby ich od Jego własnej istoty, nie może od ludzi wymagać czynów, które dla Niego samego byłyby wstrętne”30. Podobnie jak metafizycznie rozumiany świat natury również religia, jeśli ma być prawdziwa, musi być „ja-

${ }^{26}$ M. Tindal, Christianity as Old as the Creation, London 1730, ss. 11-12.

${ }^{27}$ Whichcote twierdził, że „prawdy ufundowane na zasadach rzeczy” są zawarte w teologii naturalnej. Por. B. Whichcote, Eight Letters, w: Moral and Religious Aphorisms of Dr Whichcote, London 1753, ss. 41-44).

${ }^{28}$ Por. P. Harrison, Religion and religions in the English Enlightenment, Cambridge University Press 1990, s. 31.

${ }^{29}$ M. Tindal, Christianity..., s. 18.

${ }^{30}$ Ibidem, s. 22. 
sna, prosta i naturalna”, musi być „przeznaczona dla całej ludzkości” (mankind), „dostosowana do wszystkich zdolności i odpowiednia dla każdych warunków i okoliczności życia” każdej jednostki ${ }^{31}$. Tym samym deista Tindal wyraźnie odcinał się od kalwińskiego przekonania, że wola Boga w stosunku do stworzenia jest całkowicie nieskrępowana, a Bóg działa w sposób samowolny, wręcz kapryśny.

Mając takie cechy, religia naturalna miałaby „bardzo duże znaczenie dla ludzkości”. Co więcej, byłaby ona „wiecznie obowiązującą regułą dla ludzi o bardzo małych, jak i o bardzo dużych zdolnościach”. Niosłaby z sobą „oznaki prawdy”, których oczywistości nie dałoby się zaprzeczyć32. Stąd łatwo było Tindalowi przeciwstawiać ją „religiom tradycyjnym”, czyli tym religiom, które posiadały krótszą lub dłuższą tradycję. Poreformacyjne wspólnoty religijne miały krótką tradycję, a i ta często była naznaczona egzegetycznymi sporami i podziałami. Angielski deista widział to wyraźnie na przykładzie Anglii, gdzie - zwłaszcza w XVII wieku w dużej liczbie rozmnożyły się różne wspólnoty i sekty protestanckie. Prowadziły one z sobą ostry spór doktrynalny, zarzucając sobie nawzajem fundamentalne błędy i herezje. Skoro już ich nie łączyła wspólna kalwińska tradycja, to mogło je połączyć - tak przynajmniej sądził Tindal - wspólne uznawanie prawa natury ${ }^{33}$. A ponieważ ustalanie tego prawa pozostawało domeną rozumu, to tenże rozum był w stanie tworzyć kryteria rozstrzygania o prawdziwości lub fałszywości zastanych, tradycyjnych religii. Co więcej, ludzki rozum stawał się uprawniony do tego, by rozstrzygać o tym, jakie treści i w jakiej postaci należało przyjąć w obrębie danej religii tak, aby ostatecznie była ona zgodna z treścią religii naturalnej.

Jak człowiek miał badać naturę i jej prawo? Tindal nie jest oryginalny w opisywaniu zdolności poznawczych rozumu ludzkiego. Nie dysponował jakąś własną teorią racjonalnego poznania, lecz raczej podążał - jak wielu innych w owym czasie - za Johnem Locke’em. Pod pojęciem racjonalnych zdolności Tindal rozumiał „naturalne zdolności”: „pojmowania” (apprehend), „sądzenia” (judge), i „wnioskowania” (infer). „Bezpośrednimi przedmiotami” (immediate objects) tych zdolności były nie „,zzeczy same”, lecz idee (ideas), które umysł o nich tworzy. Idee wyrażane prostymi terminami łączyły się w sądy, te zaś w twierdzenia, dalej powstawała argumentacja, do której można było stosować sylogizmy. Tindal, podobnie jak Locke, idee pojmował dwojako: jako wrażenia (sensations) i jako refleksje (reflections). Wiedza (knowledge) zasadza się na postrzeganiu zgodności i niezgodności idei (twierdzenia pozytywne i negatywne). Ale istnieje też wiedza intuicyjna (intuitive knowledge), która, wedle Tindala, sprowadza się do oczywistej prawdy, niewymagającej dowodu, czyli inaczej niż wiedza demonstratywna (demonstrative knowledge), którą uzyskuje się z pomocą innych twierdzeń, nie-

\footnotetext{
31 Ibidem, s. 218.

32 Ibidem, s. 219.

33 Ibidem, ss. 10-11.
} 
wymagających dowodu ${ }^{34}$. Wiedza intuicyjna to Boskie światło, które jest stale obecne w ludzkim umyśle ${ }^{35}$. Jest ona podstawowym i jedynym kryterium, które rozstrzyga o jakości rozumowań. Jest światłem „wewnętrznej oczywistości prawd”, które już posiadamy ${ }^{36}$. Te oczywiste prawdy tworzą zasady tzw. prawego rozumu (right reason), które są subiektywnymi odpowiednikami obiektywnej „czystości i prawości (rectitude) stworzonej przez Boga natury. Doświadczanie tej subiektywno-obiektywnej zgodności daje jednostce poczucie szczęścia, a także buduje świadomość wprowadzanych do własnego życia moralnych doskonałości Boga. Życie moralne oparte na rozpoznanych obowiązkach ma więc głęboki sens, ponieważ jest życiem szczęśliwym, czego w istocie każdy człowiek pragnie”. Stąd według Tindala sensowny jest postulat, by stale przybliżać się do najbardziej doskonałego i szczęśliwego Bytu, jakim jest Bóg. Był on poniekąd zgodny ze słowami Ewangelii: „bądźcie więc wy doskonali jak doskonały jest wasz Ojciec niebieski” (Mt 5,48). Powstawał „wspólny węzeł, który jednoczył niebo i ziemię, stworzenia i Stworzyciela" ${ }^{37}$.

\section{Rozum redukujący treści chrześcijańskiej wiary}

Jeśli chrześcijańska religia objawiona i religia naturalna mają ten sam cel, czyli dobro człowieka, i z takiej przesłanki jest wyciągany wniosek, że w obu tych religiach zasady (precepts) muszą być „te same”, to rozum działający w obszarach obu religii musi dokonywać swoistego wyrównania treści, czyli dokonać redukcji nadmiaru religijnych treści w jednej religii do poziomu tej drugiej, uboższej w treść religii. Dla Tindala religią treściowo uboższą, ale zarazem wzorcową, jest religia naturalna. Taka redukcja jest uzasadniona, gdyż ta ostatnia jest tak doskonała, że nic już do niej dodać nie można. Stąd „prawda wszelkiego objawienia powinna być osądzana w zgodności z nią”. Religia naturalna opiera się na prawie natury, a ono z kolei wspiera się na rozumie i istocie samych rzeczy ${ }^{38}$. Prawo natury jest standardem doskonałości i dzięki niemu możemy poddawać ocenie niejako a priori każdą tradycyjną religię objawionąą . Bóg nie może wyrażać się jaśniej, niż czyni to poprzez rzeczy same i relacje między nimi, które są uchwytne dla oświeconego rozumu $^{40}$. Autor Christianity as Old as the Creation zdaje się twierdzić: jeśli w ło-

34 Ibidem, s. 162.

35 Tindal określa ją jako „Boską inspirację”, pochodzącą wprost od Boga i niepochodzącą z ludzkiej dedukcji. To ta Boska inspiracja „to jednolite światło, które świeci w umysłach wszystkich ludzi, i umożliwia im rozpoznawanie” tego, czego nie dałoby się poznać z pomocą wiedzy demonstratywnej. Por. ibidem, s. 163.

36 Ibidem, s. 171.

37 Ibidem, ss. 19-20.

38 Ibidem, s. 60.

39 Ibidem, s. 51.

40 Ibidem, s. 22. 
nie protestantyzmu da się w ogóle znaleźć jakikolwiek element łączący, a zarazem dający wspólną podstawę różnym istniejącym denominacjom protestanckim, to jest nim prawo natury i w konsekwencji, religia naturalna, która jest możliwa do zaakceptowania dla każdej ziemskiej cywilizacji ${ }^{41}$.

Tindal tak bardzo wierzy ${ }^{42} \mathrm{w}$ ludzki rozum, naturalnie oświecony (czyli bez pomocy łaski) przez światło natury, że ma pretensję do teologów katolickich („papistów”), iż ci nie korzystają z racjonalnej spekulacji, by właśnie z pomocą tak oświeconego rozumu rozwikłać problem transsubstancjacji ${ }^{43}$, choć wedle angielskiego deisty leży to w ich kompetencji. Również w tym przypadku rozum miałby być sędzią odnośnie do tego, czy nasze zmysły ulegają złudzeniu, czy nie. Wedle Tindala transsubstancjacja oparta na Boskim Objawieniu jest niespójna z ludzkim rozumem, co ma dowodzić, że wypływa ona z woli Boga. Przez to „papiści” działają absurdalnie, wyolbrzymiając znaczenie tradycji i „usiłując osłabiać siły rozumu” ${ }^{44}$. Tindal nie bierze pod uwagę tego, że chrześcijańskie Objawienie zawiera treści, których akceptacja wykracza poza ludzki rozum. Nie da się ich wydedukować ze stworzonej natury, gdyż rzeczywistość transsubstancjacji jest dostępna w ponadracjonalnej wierze. Angielski deista idzie jeszcze dalej niż John Locke, który w Rozważaniach dotyczq̨cych rozumu ludzkiego w szerokim zakresie uznaje istnienie „,rzeczy ponad rozumem” (things above Reason). Miał na myśli te rzeczywistości, na które wskazywała chrześcijańska dogmatyka. W takiej sytuacji Locke postulował, by „zadowalać się wiarą i prawdopodobieństwem” ${ }^{45}$. Tindal odrzucał nawet tak rozumianą wiarę i prawdopodobieństwo, jeszcze bardziej zawężając stanowisko Johna Locke’a, który i tak był redukcjonistą, opowiadającym się za zredukowaniem prawd objawionych do absolutnego minimum ${ }^{46}$.

${ }^{41}$ Z podobnym typem myślenia spotykamy się u Immanuela Kanta w Religii w obrębie samego rozumu (tłum. A. Bobko, Znak, Kraków 1993). Kant pisał: „Religia (traktowana subiektywnie) jest poznaniem wszystkich naszych obowiązków jako przykazań Bożych. Religia, w której muszę wpierw wiedzieć, iż coś jest przykazaniem Bożym, aby uznać to za swój obowiązek, jest religią objawioną (albo potrzebującą objawienia). Natomiast ta, w której muszę najpierw wiedzieć, iż coś jest obowiązkiem, zanim mogę uznać to za przykazanie Boże, jest religią naturalną. Ten, kto jedynie religię naturalną uznaje za moralnie konieczną, tj. za obowiązek, może być nazwany racjonalistą (w sprawach wiary)” (s. 188).

42 Jest przekonany, że z tego powodu będzie cenzurowany i potępiany jako „wolnomyśliciel” (Free-Thinker), ale nie wstydzi się tego określenia, ponieważ oponenci używają słowa „wolnomyślicielstwo”, bojąc się „otwartego atakowania rozumu” w „tym Wieku Rozumu” (in this reasoning Age). Por. ibidem, ss. 158-159.

${ }^{43}$ Transsubstancjacja - przeistoczenie chleba w Ciało i wina w Krew Jezusa Chrystusa, dokonujące się podczas Ofiary Mszy Świętej w Kościele katolickim.

${ }_{44}$ M. Tindal, Christianity..., ss. 157-158.

45 J. Locke, Rozważania dotyczqce rozumu ludzkiego, tłum. B. J. Gawecki, t. 1-2, PWN, Warszawa 1955, IV, 3, 6.

${ }^{46}$ W Reasonableness of Christianity (London 1695) Locke obszernie dowodził, że tezy „Jezus Chrystus jest Mesjaszem” da się z całą pewnością racjonalnie dowieść na gruncie Pisma i przekonać wszystkich teologów z różnych denominacji, że jest to jedyna prawdziwa teza ob- 
„Pierwotne objawienie” (original revelation) to zatem objawienie wewnętrzne (światło natury), które zostało powtórzone w zewnętrznym, słownym przekazie. W przypadku chrześcijaństwa jest to przekaz Starego i Nowego Testamentu. To pierwotne objawienie poucza o „czci Boga” (honour of God) i o „dobru człowieka” (good of man). I tyle, gdyż do tego pierwotnego objawienia nie należą „,arbitralne lub jedynie pozytywne nakazy”, które nie mają na celu oddawania czci Bogu i dobra człowieka ${ }^{47}$. W tym znaczeniu - ze względu na tożsamość celów - religia objawiona jest równa religii naturalnej ${ }^{48}$. Tindal wymienia te naddatki, które nie mieszczą się w jednej i drugiej religii. Są to elementy, które w jego opinii nie wnoszą do tych religii moralnego pierwiastka. Nazywa je elementami obojętnymi (indifferent). Gdyby one miały przyczyniać się do „doskonałości objawienia”, to wtedy mnogość dodawanych elementów obojętnych tworzyłaby nieograniczony zakres objawienia. Jak się zdaje, Tindal nie bardzo wie, o czym pisze, dosyć chaotycznie podając kilka przykładów z historii Kościoła i traktując je tak, jakby one stanowiły faktyczny wyznacznik religii chrześcijańskiej, wyznawanej w Kościele powszechnym. Wymienia bowiem herezje montanizmu ${ }^{49}$, millenaryzmu ${ }^{50}$ i wiarę w wyrocznie Sybilli ${ }^{1}$, które pojawiły się w pierwszych wiekach chrześcijaństwa. Później, w XIII wieku wskazuje na ruch związany z Evangelium Aeternum ${ }^{52}$, mówi

jawiona. Oczywiście, wykraczała ona poza religię naturalną i rozum ludzki badający stworzoną naturę.

47 „Obowiązkiem prawdziwie religijnej osoby, dobrego poddanego i obywatela, są te same relacje do Boga i do człowieka; bo im bardziej czci się Boga, tym gorliwiej działa się na rzecz rodaka (patriot); im bardziej się to czyni, tym bardziej czci się Boga, ponieważ im szczęśliwsi są ludzie, tym większy mają powód, by musieć czcić Boga, który im tak uczynił” (Mt 5,16). Por. M. Tindal, Christianity..., s. 60. U Tindala oba przykazania miłości mają tę samą wagę i rozważane są na tym samym poziomie. Co więcej, sądzić można, że przykazanie pierwsze o miłowaniu Boga staje się jakby pochodnym w stosunku do drugiego przykazania dotyczącego miłowania drugiego człowieka. W Piśmie Świętym te dwa przykazania mają różną wagę - miłość do Boga jest stawiana na nieporównywalnie wyższym poziomie niż miłość bliźniego. Nie mówi się tam, że należy kochać Boga jak siebie samego, lecz by Go kochać całą duszą, całym sercem i całym umysłem. Por. Kpł 19,18, Pwt 6,5, Mt 22,37-40.

${ }_{48}$ M. Tindal, Christianity..., s. 61.

${ }^{49}$ Montanizm - ruch religijny, który powstał za sprawą Montanusa z Arlabanu (?-179), który ok. 156 r. głosił nadejście czasów Ducha Świętego i rychły ponowny powrót Jezusa Chrystusa. Ruch ten rozwijał się w II wieku we Frygii. Jego doktryna była opisywana przez historyka Kościoła Euzebiusza z Cezarei (263-339) i teologa Tertuliana (155-220).

${ }^{50}$ Millenaryzm (chiliazm) - ruch religijny głoszący bliskie nadejście tysiącletniego Królestwa Bożego, który powstał w II wieku. Wspominali o nim między innymi: św. Justyn Męczennik (100-165), św. Ireneusz z Lyonu (140-202), także Orygenes (184-253).

${ }^{51}$ Prawdopodobnie chodzi o księgi Wyroczni Sybillijskich. Pierwsze z nich były pochodzenia żydowskiego, późniejsze miały charakter chrześcijański. Zawierały między innymi hymn ku czci Jezusa Chrystusa (II-III wiek).

52 Dokładniej: Introductorius in Evangelium Aeternum - księga napisana przez franciszkanina Gerharda w 1254 r., w której wyrażono ideę „wiecznie trwającej Ewangelii”. Idea ta pochodziła od Joachima z Fiore (1135-1202). Prawdopodobnie Gerhard dokonał kompilacji z trzech wcześniejszych dzieł Joachima. 
także w sposób ogólny o „wszystkich wizjach i refleksjach” rozpowszechnionych wśród „papistów”53 oraz o „entuzjastycznych chrześcijanach”54. Tymi elementami są bądź filozoficzno-teologiczne interpretacje pewnych przesłanek objawionych, bądź bliżej nieokreślone wizje pewnych osób, o których Tindal nic konkretnego powiedzieć nie potrafi. Nie miały one prawa obywatelstwa w Kościele, gdyż po ich pojawieniu się zostały w pewnym momencie potępione i odrzucone przez Kościół.

Tindal jest bardziej konkretny, gdy uderza w Kalwina, a dokładniej w pogląd o arbitralności woli Bożej ${ }^{55}$. Genewski reformator sądził, że Bóg dysponuje niczym nieskrępowaną wolą, zgodnie z którą mógłby zmieniać, gdyby zechciał, obowiązujące przykazania moralne na dowolne inne. Kalwin pisał: „Wola Boga jest nie tylko wolna od wszelkich wad, ale jest także najwyższą zasadą doskonałości a nawet prawem wszystkich praw”56. I dalej: „Dlatego wola Boga jest tak bardzo najwyższą zasadą sprawiedliwości, że czegokolwiek Bóg chce, przez sam fakt, że tego chce, musi być uważane za sprawiedliwe. Gdy zatem ktoś pyta: dlaczego Bóg tak uczynił, to musimy odpowiedzieć, ponieważ tego chciał”57. Tindal wyraźnie oponuje przeciw takiemu stanowisku Kalwina.

Jeśli Bóg jest arbitralnym (arbitrary) Bytem i może nakazywać rzeczy wprost wedle swej woli i upodobania, pewne rzeczy dziś a inne jutro, to nie istnieje nic ani w naturze Boga ani w samych rzeczach, co przeszkadzałoby Mu ciągle zmieniać zdanie (change his mind). Gdyby raz nakazał rzeczy bez powodu, to nie byłoby żadnego powodu, dlaczego nie mógłby nieskończenie zmieniać takie nakazy ${ }^{58}$.

Jak widać, Tindal zdecydowanie odrzuca fideizm Kalwina. O ile w poprzednich przypadkach mówi bądź o jawnych herezjach, wcześniej potępionych przez Kościół katolicki, bądź o bliżej nieokreślonych błędach tego ostatniego, o tyle krytykując pojęcie arbitralnie działającego Bytu, uderza w jądro kalwińskiego fideizmu, którego najbardziej jawnym wykwitem była skrajnie pojęta kalwińska doktryna podwójnej predestynacji, wedle której - ujmując rzecz w największym skrócie - Bóg z góry nie tylko przewidział, ale i przeznaczył jednych, wybranych przez siebie ludzi, do zbawienia, innych zaś do potępienia ${ }^{59}$.

${ }^{53}$ Ta pogardliwa nazwa rzymskich katolików pochodziła od Marcina Lutra (1483-1546). Była powszechnie używana przez protestantów angielskich.

${ }^{54}$ Religijnymi „entuzjastami”, „gorliwcami” byli nazywani głównie purytanie, radykalni kalwiniści, także kwakrowie.

${ }^{55}$ M. Tindal, Christianity..., ss. 117-118.

56 J. Kalwin, Institutio, III. 23. 2.

57 Ibidem.

${ }^{58}$ M. Tindal, Christianity..., ss. 51-52.

${ }^{59}$ Oczywiście, Kalwin nie był pierwszym teologiem chrześcijańskim, który mówił o predestynacji. Pewne jej elementy można znaleźć już u Aureliusza Augustyna (354-430), nieco więcej u Williama Ockhama (1285-1349) czy Grzegorza z Rimini (1300-1358), u Kalwina pojmowanie predestynacji doprowadzone zostaje do absolutnej skrajności. 


\section{Utożsamienie religii naturalnej i chrześcijańskiej religii objawionej}

Zajmijmy się raz jeszcze kluczową kwestią utożsamienia religii naturalnej z religią objawioną, opartą na Ewangelii. Jakie argumenty filozoficzne (metafizyczne, etyczne i antropologiczne) oraz teologiczne doprowadziły Matthew Tindala do wniosku, że „religia natury jest absolutnie doskonałą religią, a zewnętrzne objawienie nie może ani dodać ani odjąć niczego z jej doskonałości”? Skąd przekonanie, że „prawdziwa religia , czy to zewnętrznie, czy wewnętrznie objawiona, musi być tą samą religią?”"60 Powtórzmy, dla Tindala główne cele obu religii są identyczne. Są nimi: oddawanie czci Bogu oraz dążenie do dobra człowieka ${ }^{61}$. Takie stanowisko było nie do pogodzenia z 39 Artykułami Wiary, które, zatwierdzone przez królową Elżbietę I, od 1563 r. stanowiły dogmatyczny fundament oficjalnego Kościoła Anglii. W dokumencie tym Czytamy między innymi: „Mają być przeklęci ci, którzy ośmielają się mówić, że każdy człowiek będzie zbawiony za pośrednictwem sekty lub prawa, które wyznawał, tak iż zgodnie z tym prawem i światłem natury gorliwie kształtował swoje życie; ponieważ Pismo Święte przedstawiło nam, że tylko w imię Jezusa Chrystusa ludzie mają być zbawieni”62. Podobnie myśleli teologowie kalwińscy zebrani na Zgromadzeniu Westminsterskim w Londynie, gdy twierdzili, że owszem „światło natury” wraz z całym stworzeniem ukazują ludziom dobroć, mądrość i moc Boga, ale pozostawiają ich bez usprawiedliwienia. Nie dają one dostatecznej wiedzy o Bogu, która jest konieczna do zbawienia ${ }^{63}$. Jednocześnie na co zwraca uwagę Peter Harrison - na tymże Zgromadzeniu pojawił się nowy pogląd, z którym nie spotykamy się u Kalwina. Otóż stwierdzono, że droga do zbawienia wiedzie nie tyle poprzez wiarę w Boskie usprawiedliwienie, ile poprzez posiadanie tzw. sumy wiedzy zbawczej ${ }^{64}$. W miejsce Boga jako przedmiotu wiary subtelnie podstawiono zestaw doktrynalnych twierdzeń, które nieco później zostały nazwane „religią objawioną”65. Była to, jak pisze Harrison, „reifikacja wiary religijnej”66. Teraz już sformułowania doktrynalne religii objawionej można było postawić niemal na tym samym poziomie dyskursu co twierdzenia religii naturalnej. To był jeden z ważnych etapów protestanckiej redukcji religii, opartej na wierze, do religii budowanej na rozumie.

${ }^{60}$ Ibidem, s. 49.

61 Ibidem, s. 59.

${ }^{62}$ The Thirty Nine Articles, Art. XVIII, w: P. Schaff, The Creeds of Christendom, $4^{\text {th }}$ ed. 3 vols, Harper, New York 1919, III; s. 499.

63 Ibidem, III, s. 600.

${ }^{64}$ P. Harrison, Religion and religions in the English Enlightenment, Cambridge University Press 1990, s. 21.

${ }^{65}$ Ibidem, ss. 21-22.

${ }^{66}$ Ibidem, s. 27. 
Dla platoników z Cambridge i swobodnych teologów (latytudynarian) było już rzeczą niemal oczywistą, że religia naturalna, choć sama w sobie niewystarczająca, jest koniecznym przygotowaniem do przyjęcia i uznania za prawdziwą religii objawionej. To na nich powołuje się Tindal. Cytuje Anthony’ego Ashley’a Lorda Shaftesbury (1671-1713), arcybiskupa Johna Tillotsona, biskupa Thomasa Sherlocka (1678-1761), także biskupa Edwarda Chandlera ${ }^{67}$ (1668-1750) i Samuela Clarke’a (1693-1766). A skoro tak, to nadszedł czas, by rozprawić się z licznymi „tradycyjnymi” wspólnotami i sektami protestanckimi. Kogo należało więc obciążyć wprowadzaniem tych „naddatków”, które okazały się tak szkodliwe dla życia religijnego, społecznego i politycznego w XVII-wiecznej Anglii? Autor Christianity as Old as the Creation winą za to obciąża duchownych wszystkich istniejących denominacji protestanckich, ale jednocześnie zauważa, że i oni poszukiwali wspólnych podstaw.

Chociaż duchowieństwo użyło wszelkich możliwych metod dla zachowania ślepej uległości (blind submission) i wymuszonej jednolitości, mimo to nie było w stanie przeszkodzić chrześcijanom w nieskończonym dzieleniu się, nawet co do tego, co nazywają podstawami (fundamentals). A choć żadna sekta, o ile wiem, nie odważyła się dać nam kompletnego zestawu ich podstaw [wiary - A.Sz.], to jednak wszystkie sekty jednomyślnie przyznają, że te rzeczy, które są konieczne do zbawienia chrześcijan, muszą być tak jasne, aby ci o najmniejszych zdolnościach mogli je poją́ć ${ }^{68}$.

Po pierwsze, duchowieństwo protestanckie, starając się przestrzegać kościelnej dyscypliny, nie było w stanie odnaleźć wspólnego zbioru fundamentalnych prawd wiary. W Kościele anglikańskim, od czasów Elżbiety I, obowiązywało 39 Artykutów Wiary. Były one jednak kontestowane przez różne sekty. Anglikański biskup Samuel Parker (1640-1688) w A Discourse of Ecclesiastical Politie (1670) szczegółowo opisał ich wzajemne spory i polemiki odnośnie do kwestii doktrynalnych. Po drugie, Tindal jest przeświadczony, że w gruncie rzeczy każda sekta dąży do wskazania pewnych, jasnych dla wszystkich, zasad wiary. Nie znaczyło to jednak, że owe ,jasne” zasady były wspólnie ustalane przez rozliczne sekty. Próby wyznaczenia doktrynalnego minimum takich wspólnych zasad, ściśle opartych na treści Pisma Świętego, podjął się dopiero John Locke w dziele The Reasonableness of Christian Religion (1695).

${ }^{67}$ W jednym z kazań Edward Chandler twierdził, że „religia naturalna jest jedyną podstawą, na której objawienie może się wspierać, i która musi być zrozumiana, zanim człowiek będzie zdolny do osądzenia natury lub oczywistości chrześcijaństwa [...] Jeśli religia naturalna nie jest częścią religii Chrystusa, to jest ledwo wartą badania tego, czym religia w ogóle jest. Jeśli tak jest, to głoszenie religii naturalnej jest głoszeniem Chrystusa. Religia Chrystusa musi być rozumiana, zanim ona może lub powinna być przedmiotem wiary; i trzeba dowieść, że jest spójną i racjonalną religią, zanim będzie można ją przyjąć”. Cyt. Za: M. Tindal, Christianity..., ss. 223-224.

${ }^{68}$ M. Tindal, Christianity..., ss. 217-218. 
Duchowni egzegeci zniekształcili biblijne Objawienie, ponieważ oni sami „nieskończenie podzielili się w interpretacji Pisma”69. Doprowadzili do tego zaciekłymi dysputami teologicznymi, które były powodem licznych niepokojów społecznych i politycznych. Wspomniany Samuel Parker pisał, że ludzie ci łączą „święty zapał w sprawie Boga” ze złośliwością i goryczą ${ }^{70}$. Przypisywał im „głupotę i ignorancję”, która niszczyła „publiczny pokój i porozumienie narodowe”. Przede wszystkim miał tu na myśli purytańskich kaznodziei, pełnych „pychy i bezczelności”, „drażliwych, ignoranckich i zuchwałych”. Anglikański biskup oceniał, że ludzie ci „zniesławiali prawdziwą pobożność”, byli hipokrytami. Określał ich jako wyniosłych, drażliwych i ponurych (sullen) wyznawców (religionists). Oskarżał o to, że są skłonni do wywoływania buntu przeciwko królowi, dążą do „rozlewu krwi i zamętu”. Miał na myśli kaznodziejów, którzy, obdarzeni ponadprzeciętną mocą perswazji, destrukcyjnie wpływali na członków swojej sekty, wywołując u słuchaczy silne emocje. Używali „nazbyt wylewnych” (fulsome) i „bujnych” (lushious) metafor oraz nośnych „biblijnych wyrażeń”. Często ich wypowiedzi jak zauważał Parker - były pozbawione sensu, tonęły w płaskim i pustym nonsensie, ograniczały się do kreowania pozornych tajemnic i różnych „fanatyzmów”. Jednym słowem zarzucał im tzw. entuzjazm (enthusiasm) ${ }^{71}$, który określał jako „czystą mistyfikację”72. Nawet jeśli przyjąć, że anglikański biskup za czasów Restauracji i rządów Karola II (1660-1685) był nazbyt stronniczy, to nie można tak powiedzieć o wszystkich świadkach tej epoki. Daniel Featley (1582-1645) przypisywał przywódcom sekt ciąg nieszczęść, jakie spłynęły na Anglię i Szkocję. Pisał: „Nieszczęść naszych późnych i wyniszczających chorób nie zapomnieliśmy, bowiem nasz kraj został przesycony krwią, a nasze ubrania wytarzane we krwi, nasze życie nieśliśmy w swoich rękach, a nasze posiadłości były wystawione na grabież: herezje i schizmy zjadały jak gangrena, a religia zatraciła się w ateizmie, bluźnierstwie, epikureizmie i swobodzie politycznej tych rozwiązłych czasów”73. Podobne świadectwo składał, znacznie wcześniej niż Parker, purytanin Thomas Edwards (1599-1647), który wspominał: „Nigdy nie było większych, jak w naszych czasach, samolubców (selfe-seekers), pyszałków, bluźnierców, łamiących przymierze, niewdzięczników, podjudzaczy (make-bates), piorących mózgi (heady), pogardzających dobrymi ludźmi, prześmiewców, szyderców, idących za swoimi bezbożnymi przyjemnościami, pogardzających władzą, i mówiących źle

69 Ibidem, s. 233.

70 S. Parker, A Discourse of Ecclesiastical Politie, London 1670, s. 13.

71 Nieco później John Tillotson zdefiniował „entuzjazm” jako postawę irracjonalną i fideistyczną, charakterystyczną dla religijnego fanatyzmu. Entuzjazm to duchowa namiętność, która nie jest współmierna z poznaniem przedmiotu, do którego ta namiętność się odnosi. J. Tillotson, Sermo XXVIII - The Danger of Zeal, without Knowledge, Works, vol. IV, London 1743, ss. 375-386.

72 S. Parker, A Discourse..., ss. 76-77.

73 D. Featley, The League illegal, Publishers Introduction, The Introduction, London 1660. 
o ludziach wysokiej rangi" ${ }^{74}$. Warto przywołać również ówczesnego publicystę Rogera L’Estrange (1616-1704), który zwracał uwagę na to, że członkowie sekt mianowali się jedynymi prawdziwymi obrońcami wiary Chrystusa, innych nazywając antychrystami ${ }^{75}$.

Późniejszy historyk Marsden podsumowywał, że owe „schizmatyckie sekty” szczególnie rozmnożyły się za rządów większości parlamentarnej purytanów i protektoratu Olivera Cromwella. Cechowała je niezdolność do kompromisu, wzajemne animozje i zajadłość wobec siebie ${ }^{76}$.

Anglia przez dwadzieścia lat była ogłuszana religijnymi polemikami. Na każdej kazalnicy były dyskutowane formy zarządu Kościoła - prezbiterianizm i prałatura, roszczenia independentów i zgiełk sekciarzy (sectaries), prawa pastorów i prawa wiernych. Rozpraszali każdą parafię i każdy dom. Wrzawa była nieustanna, i jest zdumiewające, że prawdziwa religia nie została zagłuszona przez ten wrzask ${ }^{77}$.

Nic więc dziwnego, że w następnym wieku Matthew Tindal tak niechętnie odnosił się do wykrzywionej na wszelkie możliwe sposoby religii objawionej, a dokładniej: do niekończących się sporów, polemik i wzajemnych oskarżeń o błędną egzegezę Pisma Świętego i o heretyckie sformułowania teologicznych doktryn. Stąd u Tindala i wielu jemu współczesnych pojawił się dosyć niefortunny pomysł, by redukować chrześcijaństwo do zasad moralności, ujawniających się w nakazach sumienia. Odtąd ściśle religijna część chrześcijaństwa miała zostać zepchnięta na margines, zaś na plan pierwszy wkraczała moralność, mającą podstawę już nie tylko w chrześcijaństwie, ale nade wszystko w pozakonfesyjnym prawie natury. Angielskiemu deiście religia naturalna wydawała się religią czystą, niezależną od teologicznej aktywności duchowieństwa i wolną od „przesądów”, które wedle opinii Tindala sprowadzały się do „nienaturalnych pojęć boskości”. Ich akceptacja powodowała „szkodliwe skutki”. Były one bowiem „całkowicie niezgodne z naturą Boga” i „przeciwne ludzkiemu rozumowi”78. Tindal uderzał w radykalnych purytanów, gdy oskarżał ich o to, że czynią oni Boga niesprawiedliwym, okrutnym i niespójnym Bytem. Ci bigoci myślą - zauważał Tindal - że mają władzę karania wszystkich tych, którzy różnią się od nich w kulcie religijnym, uznając

${ }^{74}$ Th. Edwards, Gangraena, London 1646, part III, ss. 256-257.

75 „O Panie, Twoja cześć jest obecnie zagrożona, bo teraz, o Panie, Antychryst wyciągnął swój miecz przeciwko Twojemu Chrystusowi. I jeśli nasi nieprzyjaciele zwyciężą, Ty stracisz swoją cześć”. Kazanie jednego z kaznodziejów - Stricklanda w Southhampton, 9 czerwca 1643 r. Inny (Crosse) narzekał: ,jeśli nie zakończysz dobrego dzieła, które zacząłeś poprzez reformację Kościoła, pokaże się, że jesteś Bogiem zamętu” (the God of Confussion). To spowoduje „destrukcję Twoich własnych dzieci” (S. Mildreds in the Counter, 6 czerwca 1643 r.). Por. R. L’Estrange, Dissenters Sayings, London 1681, s. 7.

${ }^{76}$ J.B. Marsden The History of the Later Puritans, London 1852, ss. 77-78.

77 Ibidem, ss. 234-235.

${ }^{78}$ M. Tindal, Christianity..., s. 76. I tu Tindal nie jest oryginalny. W podobny sposób o przesądzie pisali: platonik John Smith (1618-1652) i anglikański biskup John Tillotson. 
ich za wrogów Boga ${ }^{79}$. Dla autora Christianity as Old as the Creation w myśleniu o Bogu przesądem zdawało się być wszystko to, co nie dawało się wyprowadzić z rozumowań logicznych i metafizycznych. Podporządkowywał on spekulacji metafizycznej obraz Boga, jaki wyłaniał się z kart Pisma Świętego.

„Zdrowe sądy w sprawach religii” miały zakotwiczenie również w sferze moralnej, która była dziełem światła rozumu. To był fundament religii naturalnej, który miał zastąpić całą strukturę teologiczną, opartą na „źle interpretowanych tekstach”. Dzięki niemu możliwa była „nadnaturalna miłość, która nie niszczy naturalnych ludzkich uczuć”, zaś „,wiary w Boga nie łączy z nienawiścią bliźniego”. Dla Tindala naturalna część religii była określona przez prawo naturalne (prawo moralne), a drugą część religii stanowił kalwiński przesąd (superstition), który należało odrzucić. Zewnętrzne Objawienie, nie mogło czynić wolą Bożą czegoś, co światło natury przedstawiało jako niegodne Boga jako jej Autora ${ }^{80}$. Ostrze tej krytyki było skierowane wprost przeciw Kalwinowi.

\section{Ewangelia jako ponowne wydanie religii naturalnej}

Do czego więc potrzebne jest deiście Tindalowi przesłanie Nowego Testamentu? Owszem, aprobuje go, ale w bardzo ograniczonym zakresie. W jego oczach Jezus Chrystus był minimalistą, bowiem nie nauczał o nowych obowiązkach ani czymkolwiek innym, lecz jedynie o konieczności dokonywania aktów skruchy z powodu naruszania znanych wszystkim obowiązków moralnych. Co więcej, takie przesłanie kierował zarówno do Żydów, jak i do pogan. Chrystus nie przyszedł do całego Izraela, lecz tylko do „zagubionych owiec” (Mk 2,17). Przyszedł nie do sprawiedliwych, lecz jedynie po to, by grzeszników wezwać do skruchy, jako że z nawrócenia jednego grzesznika więcej jest radości w niebie niż z dziewięćdziesięciu dziewięciu sprawiedliwych (Łk 15,7) ${ }^{81}$. Tindal właściwie zrównuje misję Jezusa z posłannictwem Jana Chrzciciela, który chrzcił nad Jordanem oraz głosił potrzebę pokuty i nawrócenia. To kolejny element redukcji treści dotychczasowego chrześcijaństwa. „Absolutnie doskonałe Prawo” zostało ogłoszone Żydom jako coś zewnętrznego. Ale nie ma to większego znaczenia - sądzi Tindal - bo nie jest ono inne od tego prawa, które Bóg każdego dnia wszczepia w umysły wszystkich ludzi (także niechrześcijan). I czynił to także przed przyjściem Chrystusa. Oparte na tym samym Prawie religie, zewnętrzna (objawiona) i wewnętrzna (naturalna), nie mogą się różnić. By gdyby się różniły, to to Prawo Ewangelii różniłoby się od prawa natury. To by zaś znaczyło, że wola Boga nie jest niezmienna. A każda różnica wskazywałaby na ukonstytuowanie się jakiejś nowej religii ${ }^{82}$.

\footnotetext{
${ }^{79}$ Ibidem, s. 88.

${ }^{80}$ Ibidem, ss. 56-57.

${ }^{81}$ Ibidem, s. 41.

${ }^{82}$ Ibidem, s. 49-51.
} 
Cokolwiek jest prawdziwe dzięki rozumowi, nigdy nie może być fałszywe dzięki objawieniu, i jeśli Bóg nie może zwodzić samego siebie, lub zwodzić ludzi, to światło, które dał, by rozróżniać pomiędzy religijną prawdą i fałszem, nie może [...] zwodzić ich w rzeczach tak wielkiej wagi ${ }^{83}$.

Jeśli więc religia naturalna jest pierwotna w stosunku do religii objawionej, to zrozumiałe staje się twierdzenie Tindala, powtarzane zresztą za biskupem Sherlockiem $^{84}$, że „religia Ewangelii jest prawdziwą oryginalną religią rozumu i natury”. Ewangelia zatem nie jest niczym innym jak ponownym ogłoszeniem (republication) prawa natury. Nie pojawia się wraz z początkiem publicznej misji Jezusa Chrystusa i Apostołów, lecz jest tak „stara jak stworzenie”. Jeśli więc wskazania Ewangelii są niezmienne, to jest tak dlatego, że religia naturalna pozostaje ta sama w każdej epoce. Zbawiciel przyszedł na świat nie po to, by uzupełnić braki religii naturalnej, lecz raczej braki ludzkiej natury, zobowiązując ludzi do życia zgodnie z prawem naturalnym (natural law) w niezmiennej czystości i doskonałości ${ }^{85}$. Wedle słów Tindala to raczej rozum dąży do „wypełnienia (supply) braków objawienia” niż objawienie do uzupełnienia „braków rozumu”. Przy okazji raz jeszcze dystansuje się od kalwinizmu, wskazując na wiele niejasnych miejsc w Piśmie Świętym, jeśli interpretuje się je w sposób dosłowny. Doradza teologom, by odchodzili od owej dosłowności i odkrywali w Piśmie sensy zgodne z rozumem ${ }^{86}$. U Kalwina właściwe odczytanie biblijnych sensów gwarantował wierzącemu Duch Święty, dla angielskiego deisty jedynym interpretatorem Pisma Świętego jest ludzki rozum. Stąd ten ostatni deklaruje, że „wszystkie zasady chrześcijaństwa są rozumne i mądre”, i określają takie obowiązki, które są zgodne z naturą i z „najlepszym rozumem ludzkości” (best Reason of Mankind) ${ }^{87}$.

Tindal nie zgadza się z tymi, którzy twierdzą, że relacje Bóg-człowiek winny być definiowane poprzez wiarę, której z kolei powinien być podporządkowany rozum. Nie zgadza się, by zakres poznania przez wiarę był większy niż przez rozum. Odrzuca wiarę, gdyż - jak sądzi - dostarcza nam ona „prostackiego fałszu” (vulgar false), przez co nabywamy „bezwartościowych pojęć o Boskiej istocie”, przypisując Bogu różne ludzkie niedoskonałości, a nawet „najgorsze z ludzkich namiętności” (the worst of human passions). Tindal cytuje Tillotsona: „W zależności od tego, jakie pojęcia o Bogu mają ludzie, taka będzie ich religia. Jeśli mają grubiańskie (gross) i fałszywe pojęcia o Bogu, ich religia będzie absurdalna i zabobonna"88. Tindal gorszy się tym, że wiele poleceń danych przez Boga prorokom, jeśli brać

${ }^{83}$ M. Tindal, Christianity..., s. 157.

${ }^{84}$ W. Sherlock, Sermons before the Society for Propagating the Gospel, London 1688, s. 16.

${ }^{85}$ M. Tindal, Christianity..., ss. 68-70.

${ }^{86}$ Ibidem, ss. $178-179$.

87 Ibidem, s. 27.

${ }^{88}$ Ibidem, s. 64. Cyt. za Tindalem. Por. także J. Tillotson, The Works, vol. I, London 1722, s. 181. 
je dosłownie, wydają się niegodne Boga, gdyż skłaniają ludzi do szaleństwa i zachowań irracjonalnych ${ }^{89}$. Ma tu na myśli Stary Testament.

\section{Zakończenie}

Matthew Tindal zasadniczo inaczej postrzega naturę ludzką niż Thomas Becconsall. Odrzuca pogląd tego ostatniego - choć nie expressis verbis - że natura ludzka jest obciążona pewnym moralnym niedowładem, który objawia się większą skłonnością do popełniania moralnego zła niż dobra. To doświadczenie moralne znane od starożytności, przez wieki znajdowało wyjaśnienie w jednej z podstawowych prawd religii chrześcijańskiej - w dogmacie o grzechu pierworodnym i jego dziedzicznych skutkach dla ludzkości. Angielscy protestanci, niemalże do czasów swobodnych teologów włącznie, nie podważali tego dogmatu. Nie obalał go również Thomas Becconsall, jeden z wielkich zwolenników religii naturalnej. Tindal natomiast milcząco zakłada stan natury ludzkiej jakby sprzed Upadku. Zatem nie traktuje jej jako skażonej jakąś dziedziczną ułomnością, pojmuje ją jako czystą, z której rozum ludzki jest w stanie bezbłędnie odczytywać szereg moralnych powinności. Tindal jest deistą, nie ateistą, jest bowiem przekonany o istnieniu Boga jako Stworzyciela świata i człowieka. Owszem, Bóg komunikuje się z człowiekiem, ale w sposób istotny (wiedzotwórczy) tylko za pomocą dzieła stworzenia. Jeśli w historii przekazywał coś wprost w Objawieniu dawanym prorokom, to w istocie powtarzał te treści, które zawarł w swoim stwórczym dziele, a które rozum ludzki może bez większych przeszkód odkryć w nim sam. Tindal nie neguje istnienia zła moralnego, ani grzechu, ale do ich usunięcia wystarczają ludzkie siły; nie potrzeba Boskiej łaski, a nawet Boskiego Odkupienia. Rolę Chrystusa ogranicza jedynie do nawoływania do podejmowania moralnej poprawy. Jego zbawcza śmierć i zmartwychwstanie nie ma dla angielskiego deisty większego znaczenia. Objawienie Starego i Nowego Testamentu niczego nowego nie wnosi. Jest właściwie powtórzeniem tego, co od Boga otrzymuje ludzki rozum, oświecony w sposób naturalny dzięki uczestnictwu w Boskiej mądrości. Owo oświecenie jest naturalne, nie nadnaturalne dzięki łasce. Tindal lekceważy treści objawione, obecne w różnych denominacjach religii chrześcijańskiej. Nazywa je „naddatkami”, treściami obojętnymi dla naszego poznania, które funkcjonują jako przesądy. W ponad 150-letniej ewolucji angielskiej myśli protestanckiej autor Christianity as Old as the Creation dokonuje na ostatnim etapie końcowej redukcji chrześcijaństwa do religii naturalnej. To ostatni etap, poprzedzony wieloma wcześniejszymi. Już sam kalwinizm był znaczącą redukcją katolicyzmu, później w podobnym kierunku szły liczne sekty protestanckie, następnie platonicy, swobodni teologowie i John Locke.

${ }^{89}$ Tindal cytuje: Iz 20,3, Jr 13,4-6, Ap 10,9. Por. M. Tindal, Christianity..., s. 229. 
Oświecony rozum wskazywał na Boga, ale nie bezpośrednio, lecz poprzez materialny świat, którego wystarczało badać w sposób racjonalny zarówno w sensie metafizycznym, etycznym, a później także na gruncie nauk przyrodniczych. W istocie od deizmu do ateizmu był już tylko niewielki krok. Angielskie Oświecenie, wynoszące na piedestał oświecony rozum, początkowo miało deistyczny charakter, ale już na Kontynencie (zwłaszcza we Francji) dosyć szybko przybrało ateistyczną postać i stało się promotorem ateistycznego postępu. Ten proces nie byłby jednak możliwy bez angielskich deistów (zwłaszcza Tindala). Wyciągnęli oni ostateczne wnioski z protestanckiego pluralizmu religijnego, który doprowadził do rozmycia tożsamości chrześcijańskiej religii objawionej.

\section{Literatura}

Atkey A., The Main Argument Of a late Book, Intitled Christianity as Old as the Creation, London 1733.

Atkinson B., Scripture History, Precepts and Prophecy Vindicated... of Christianity not older than the First Gospel-promise, in Answer to Christianity as Old as the Creation, London 1731.

Augustyn, Contra Julianum, Patrologia Latina, t. 44.

Becconsall Th., The Grounds and Foundation of Natural Religion, London 1698.

Browne S., The Close of the Defense of the Religion of Nature and the Christian Revelation: in Answer to Christianity as Old as the Creation, London 1733.

Chilligworth W., The Religion of Protestants. A Safe Way to Salvation, London 1638. Edwards Th., Gangraena, London 1646.

Featley D., The League illegal, Publishers Introduction, The Introduction, London 1660.

Formuła Zgody z 1577 roku, przeł. bp Józef Pośpiech, Ośrodek Wydawniczy „Augustana”, Bielsko-Biała 1999.

Harrison P., Religion and religions in the English Enlightenment, Cambridge University Press 1990.

Kalwin J., Institutio christianae religionis, Genevae 1559.

Kant I., w Religii w obrębie samego rozumu, tłum. A. Bobko, Znak, Kraków 1993.

Lalor St., Matthew Tindal. Freethinker. An Eighteens-Century Assault on Religion, Continuum, London \& New York 2006.

Leland J., An Answer to a Book Intituled Christianity as Old as the Creation, London 1740. L’Estrange R., Dissenters Sayings, London 1681.

Locke J., The Reasonableness of Christianity, w: Works, vol. 1-10, London 1823, vol. 7. Marsden J. B., The History of the Later Puritans, London 1852.

Nye St. A Discourse Concerning Natural and Revealed Religion, Glasgow 1696.

Parker S., A Discourse of Ecclesiastical Politie, London 1670.

Shaff Ph., The Thirty Nine Articles, Art. XVIII, w: The Creeds of Christendom, $4^{\text {th }}$ ed. 3 vols, Harper, New York 1919, III.

Sherlock W., Sermons before the Society for Propagating the Gospel, London 1688.

Szwed A., Fideizm Kalwina i bunt angielskich racjonalistów, Wydawnictwo Marek Derewiecki, Kęty 2016. 
Tillotson J., Of the Great Duties of Natural Religion, Works, vol. I-II, London 1722.

Tillotson J., Works, vol. I-XII, London 1743.

Tindal M., Christianity as Old as the Creation, London 1730.

Waterland D., Scripture Vindicated. In Answer to a Book Christianity as Old as the Creation, London 1730.

Whichcote B., Eight Letters, w: Moral and Religious Aphorisms of Dr Whichcote, London 1753.

Wilkins J., Of the Principles and Duties of Natural Religion, London 1675. 